\title{
Erratum to: Condition factor, Length - Weight relationship, and the fishery of Barbus altianalis (Boulenger 1900) in Lakes Victoria and Edward basins of Uganda
}

\author{
C. C. Ondhoro • C. Masembe • G. E. Maes • \\ N. W. Nkalubo • J. K. Walakira • J. Naluwairo • \\ M. T. Mwanja $\cdot$ J. Efitre
}

Published online: 12 January 2017

(C) Springer Science+Business Media Dordrecht 2017

\section{Erratum to: Environ Biol Fish DOI:10.1007/s10641-016-0540-7}

The original version of this article was revised to standardize units of measurement. The changes are underlined as follows:

\section{9th sentence under Abstract}

Catch rates varied between River Nile $(1.92 \pm 0.59$

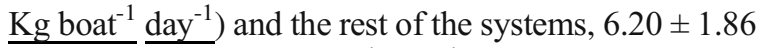
$\overline{\text { and } 6.85} \pm 1.49 \underline{\mathrm{Kg} \mathrm{boat}^{-1}} \underline{\text { day }^{-1}}$ in Lake Edward and Kazinga channel respectively.

\section{11th sentence under Abstract}

Dissolved oxygen was below the minimum of $5 \underline{\mathrm{mgl}^{-1}}$ required for the physiology of freshwater fish.

The online version of the original article can be found at http://doi. dx.org/10.1007/s10641-016-0540-7.

\section{C. Ondhoro $(\bowtie)$}

Buginyanya Zonal Agricultural Research and Development, Institute, P.O. Box 1356, Mbale, Uganda

e-mail: occonstantine88@gmail.com

C. C. Ondhoro · J. K. Walakira • M. T. Mwanja Aquaculture Research and Development Centre Kajjansi, P.O. Box 530, Kampala, Uganda

C. C. Ondhoro $\cdot$ C. Masembe $\cdot$ J. Efitre

Department of Zoology, Entomology and Fisheries Sciences, Makerere University, P.O. Box 7062, Kampala, Uganda

\section{12th sentence under Abstract}

Conductivity was highest in Lake Edward (312 $\mu \mathrm{S} \mathrm{cm}{ }^{-1}$ ), followed by Kazinga channel and least in River Nile.

\section{5th sentence, paragraph 2 under Introduction}

Catch rates in the Lakes Victoria and Edward basins reduced to the lowest levels of 0.5 to $0.2 \mathrm{kgh}^{-1}$ (Bekkevold et al. 2005; Chande and Mhitu 2005; Ntakimazi 2006) in the 1970s, and further declined to $0.06 \mathrm{kgh}^{-1}$ in Lake Victoria (Chande and Mhitu 2005).

5. 1st sentence, paragraph 2 under Water quality data collection

Dissolved oxygen $\left(\mathrm{mgl}^{-1}\right)$, water temperature $\left({ }^{\circ} \mathrm{C}\right)$, electrical conductivity $\left(\overline{\mathrm{S} \mathrm{cm}}^{-1}\right)$ and $\mathrm{pH}$ were determined using Yellow Spring Instrument (YSI, model 556) at

\section{G. E. Maes}

Laboratory of Biodiversity and Evolutionary Genomics, University of Leuven (KU Leuven), B-3000 Leuven, Belgium

\section{G. E. Maes}

Centre for Sustainable Tropical Fisheries and Aquaculture, Comparative Genomics Centre, College of Science and Engineering, James Cook University, Townsville, Qld 4811, Australia

N. W. Nkalubo $\cdot$ J. Naluwairo

National Fisheries Resources Research Institute, P.O. Box 343, Jinja, Uganda 
mid-water and between 07:00 $\mathrm{h}$ to $08: 30 \mathrm{~h}$ to generate monthly average water quality observations for each population.

6. 5th sentence, paragraph 4 under Extinction upstream Owen falls dam and variation in Condition between populations section

Whereas dissolved oxygen levelcpss in River Nile was higher than in Lake Edward and Kazinga channel, the concentration recorded is still lower than the usual recommended minimum of $\geqq 5 \mathrm{mgl}^{-1}$. Boyd (1998) provides water quality benchmarks for fresh water fishes within the range of 5-15 $\mathrm{mgl}^{-1}$.

7. 7th sentence, paragraph 4 under Extinction upstream Owen falls dam and variation in Condition between populations section

Elsewhere, $8.7 \mathrm{mgl}^{-1}$ (Abowei 2010); Arumlampalam et al. (1998), documented dissolved oxygen levels of 5.54-7.98 $\mathrm{mgl}^{-1}$ in fresh water fisheries of the upper Gulf of Thailand and Malaysia respectively.

The original article was corrected. 